\title{
Pengaruh Pembelajaran Luar Kelas (Outdoor Learning) Terhadap Kemampuan Pemecahan Masalah Siswa Kelas VII SMP Negeri 05 Seluma
}

\author{
${ }^{1}$ Budi Taqwan, ${ }^{2}$ Saleh Haji \\ ${ }^{1}$ Guru SMPN 25 Seluma, ${ }^{2}$ Pendidikan Matematika Universitas Bengkulu \\ Koresponden: taqwanbudi@gmail.com
}

\begin{abstract}
Abstrak
Penelitian ini bertujuan untuk melihat pengaruh Pembelajaran Luar Kelas (Outdoor learning) dan Gaya belajar terhadap Kemampuan pemahaman konsep dan kemampuan pemecahan masalah pada siswa SMP Negeri 05 Seluma. Jenis penelitian ini adalah quasi experimen yang dipilih dalam penelitian ini siswa kelas $\mathrm{VII}_{1}$ sebagai kelas Ekperimen dan kelas $\mathrm{VII}_{2}$ sebagai kelas kontrol.Pengumpulan data dilakukan dengan menggunakan lembar test kemampuan lember test untuk kemampuan pemecahan masalah. Tehnik analisis data terdiri dari tehnik analisis uji coba intrumen dan analisis uji hipotesis.analisis hipotesis penelitian menggunakan mancova hasil penelitian menunjukkan bahwa terdapat pengaruh pembelajaran luar kelas (Outdoor learning) dan gaya belajar terhadap kemampuan kemampuan pemecahan masalah siswa SMP negeri 05 Seluma. Besar pengaruh pembelajaran luar kelas (Outdoor learning) dan gaya belajar terhadap kemampuan Pemecahan Masalah 97,3\%.
\end{abstract}

Kata Kunci : Pembelajaran luar kelas (Outdoor learning), mathematical problem solving abilities

\section{PENDAhUluAN}

Pada dasarnya semua orang tidak menghendaki kebosanan dalam hidupnya. Demikian juga dalam proses belajar mengajar, bila guru dalam proses belajar mengajar tidak menggunakan metode pembelajaran yang melibatkan siswa, maka akan membosankan siswa. Apabila siswa merasa bosan dalam belajar maka perhatian siswa akan berkurang, mengantuk, akibatnya tujuan belajar tidak tercapai. Teknik pembelajaran yang kurang melibat siswa maka akan menyebabkan siswa kurang berminat untuk mengikuti proses belajar mengajar. Hal ini disebabkan oleh metode pembelajaran yang monoton dari waktu kewaktu. Salah satu cara agar informasi dapat diserap dan kemudian dimasukkan kedalam memori jangka panjang adalah apabila informasi tersebut mengandung kekuatan emosi, baik suka (emosi positif) maupun duka (emosi negatif). Semua guru sangat mengharapkan agar materi yang disampaikan kepada semua siswanya dapat dimasukkan ke memori jangka panjang dan bahkan tidak terlupakan seumur hidup. Untuk mengatasi hal tersebut maka guru harus selalu meningkatkan kualitas profesionalnya yaitu dengan memberikan kesempatan belajar kepada siswa dengan melibatkan siswa secara aktif dalam proses pembelajaran. Gurujuga harus berperan dalam menimbulkan hubungan yang erat dengan guru, teman-temannya dan juga dengan lingkungan sekitarnya.

Menurut Adelia Vera (2012:17) mengemukakan bahwa :"Metode mengajar diluar kelas khususnya adalah kegiatan belajar-mengajar antara guru dan murid,namun tidak dilakukan di dalam kelas,tetapi dilakukan di luar kelas atau alam terbuka,sebagai kegiatan pembelajaran siswa.misalnya,bermain dilingkungan sekolah,taman,perkampungan pertanian,nelayan,berkemah dan kegiatan yang bersifat petualangan, serta perkembangan aspek pengetahuan yang relevan”.

Pembelajaran outdoor learning merupakan satu jalan bagaimana kita meningkatkan kapasitas belajar anak. Anak dapat belajar secara lebih mendalam melalui objek-objek yang dihadapi dari pada jika belajar di dalam kelas yang memiliki banyakketerbatasan. Lebih lanjut, belajar diluar kelas akan dapat menolong anak untuk mengaplikasikan pengetahuan yang dimiliki. Selain itu, pembelajaran di luar kelas lebih menantang bagi siswa dan menjembatani 
antara teori di dalam buku dan kenyataan yang ada di lapangan. Kualitas pembelajaran dalam situasi yang nyata akan memberikan peningkatan kapasitas pencapaian belajar melalui objek yang dipelajari serta dapat membangun keterampilan sosial dan personal yang lebih baik. Dari pendapat di atas dapat disimpulkan bahwa dengan belajar diluar kelas, para peserta didik atau para siswa akan beradaptasi dengan lingkungan, alam sekitar, serta dengan kehidupan masyarakat. metode pembelajaran diluar kelas yang melibatkan siswa akan menunjukkan ketekunan, semangat, antusiasme, serta penuh partisipasi antar sesama siswa dan guru. Pola interaksi guru dengan siswa dalam kegiatan pembelajaran menurut keterampilan guru dalam mengelola kegiatan tersebut. Penerapan metode pembelajaran diluar kelas ( outdoor Learning ) dalam pembelajaran yaitu dengan cara siswa Kelas VIII A SMP Negeri 05 Seluma melakukan kegiatan belajar di luar kelas atau dilingkungan sekolah, alam sekitar atau pun masyarakat. Dalam proses pembelajaran di luar kelas, guru mesti memperhatikan betul cara bersikap ketika mengajar siswa Kelas VIII A SMP Negeri 05 Seluma di luar kelas. karena, sikap dan perilaku dalam kegiatan belajar-mengajar di luar kelas sangat menentukan keberhasilan para siswa Kelas VIII A SMP Negeri 05 Seluma dalam belajar. Secara garis besar, ketika seorang guru mengajar para siswa di luar kelas ia tidak hanya sebagai seorang guru, melainkan sebagai fasilitator, teman pelatih, dan motivator. Kenyataan di lapangan didapati bahwa masih banyak siswa pada SMP Negeri 05 Seluma belum dapat berinteraksi secara aktif dalam mencapai hasil belajar yang memuaskan disebabkan minat belajar siswa yang kurang. Hal ini disebabkan diantaranya oleh teknik pembelajaran yang di gunakan di SMP Negeri 05 Seluma masih menggunakan metode konvensional dimana dalam proses pembelajaran guru yang lebih dominan atau pro aktif siswa hanya menjadi pendegar saja sehingga dalam kegiatan pembelajaran siswa merasa jenuh dan tidak bersemagat sehingga tujuan intisari pembelajaran tidak tercapai sepenuhnya.

Pembelajaran di luar kelas (Outdoor learning) dan gaya belajar sudah pernah dilakukan oleh beberapa dewan guru akan tetapi dalam kegiatan pembelajarannya guru belum sepenuhnya melibatkan siswa dalam proses pembelajaran. Masih dijumpai guru yang memberikan metode belajar di luar kelas sebagian besar tidak melibatkan siswa namun masih di dominasi oleh guru itu sendiri. Dilihat dari faktor siswa pun belum dapat mengeluarkan pengalaman apa yang didapat ketika belajar di luar kelas, masih terdapat siswa kelas VII SMP Negeri 05 Seluma yang bermain ketika pembelajaran di luar kelas dilaksanakan sehingga tujuan pembelajaran tidak tercapai dan waktu terbuang sia-sia. Manfaat pembelajaran di luar kelas (Outdoor Learning) adalah (1) Pikiran Lebih jernih, (2) Pembelajaran akan terasa menyenangkan, (3) Pembelajarannya lebih Variatif (4) Belajar lebih kreatif, (5) Belajar lebih riil, (6) Anak lebih mengenal pada dunia nyata dan luas, (7) Tertanam image bahwa dunia sebagai kelas, (8) Wahana belajar akan lebih Luas, (9) Kerja Otak Lebih Rilex. Melihat manfaat dari outdoor Learning maka peneliti merasa motode pembelajaran luar kelas (Outdoor Learning) cocok diterapkan di SMP Negeri 05 Seluma khususnya di Kelas VIII $^{1}$, mudah- mudahan kesulitan dalam belajar matematika bisa diatasi dengan baik. Pendekatan pembelajaran diluar kelas ini memiliki kelebihan yang mendukung pada pembelajaran siswa, di antaranya sebagai berikut :

1. Mendorong motivasi belajar siswa, karena menggunakan setting alam terbuka sebagai sarana kelas, untuk memberikan dukungan proses pembelajaran secara menyeluruh yang dapat menambah aspek kegembiraan dan kesenangan. 
2. Guru mampu menciptakan suasana pembelajaran yang menyenangkan karena dapat berekspolarasi menciptakan suasana belajar seperti bermain.

3. Pada pembelajaran di luar kelas siswa menggunakan media pembelajaran yang kongkrit dan memahami lingkungan yang ada disekitarnya. Pada saat pembelajaran digunakan media yang sesuai dengan situasi kenyataannya, yakni berbagai permainan anak seperti seluncuran, ayunan, jungkat-jungkit dan lain-lain.

4. Mengasah aktivitas fisik dan kreativitas siswa karena menggunakan strategi belajar sambil melakukan atau mempraktekan sesuai dengan penugasan. Selain memiliki kelebihan, pendekatan diluar kelas sebagai pendekatan pembelajaran juga memiliki kelemahan: memerlukan perhatian yang ekstra dari guru pada saat pembelajaran karena menggunakan media yang sesuai dengan kenyataannya di arena bermain anak yang dapat memungkinkan anak keterusan bermain di tempat tersebut.

Penelitian ini menunjukkan bahwa gaya belajar merupakan faktor penting dalam pencapaian siswa (Cano \& Garton, 1994). Putih (1970) menegaskan ada pola perubahan intelektual yang terjadi pada mahasiswa. Seperti tahap perkembangan anak usia dini seperti yang dijelaskan oleh Piaget, Perry. (1970), menunjukkan bahwa perkembangan dasar dalam cara berpikir untuk seorang siswa selama pengalaman kuliah ada. Perry (1970) lebih lanjut menyatakan bahwa perkembangan dasar ini mempengaruhi instruktur dan / atau penasihat siswa untuk mencari cara alternatif untuk mengajar dan memberi saran. White (1970) dan Lyons (1984) mendorong para guru yang berharap dapat memupuk pentingnya perkembangan dasar dalam pengembangan perubahan intelektual, untuk mempraktikkan seni mereka dengan fleksibilitas responsif dalam upaya mempertahankan lebih banyak siswa.

Dalam studi sebelumnya, telah dicatat korelasi dalam bagaimana seorang pelajar belajar, diukur dengan gaya belajar, dan seberapa banyak pelajar belajar, diukur dengan nilai rata-rata kumulatif (Torres, 1993; Torres \& Cano, 1993). Temuan lain menunjukkan bahwa siswa yang lebih mandiri dalam pemikiran mereka, lebih berhasil dalam pendidikan tinggi (Porter \& Cano,1996). Apa implikasinya terhadap siswa yang lebih bergantung pada pemikiran mereka? Apakah siswa berpikiran dependen sama suksesnya dengan rekan mereka dalam pendidikan tinggi? Bagi para pendidik yang berkomunikasi, berinteraksi, dan mengajar siswa setiap hari, pengetahuan yang didapat dari belajar tentang hubungan antara gaya belajar dan prestasi akademik hanya dapat membantu keberhasilan akademik siswa.

Menurut Fleming dan Mills (1992), gaya belajar merupakan kecenderungan siswa untuk mengadaptasi strategi tertentu dalam belajarnya sebagai bentuk tanggung jawabnya untuk mendapatkan satu pendekatan belajar yang sesuai dengan tuntutan belajar di kelas/sekolah maupun tuntutan dari mata pelajaran.

Drummond, (1998:186). Mendefinisikan gaya belajar sebagai, "an individual's preferred mode and desired conditions of learning." Maksudnya, gaya belajar dianggap sebagai cara belajar atau kondisi belajar yang disukai oleh pembelajar.

Willing, (1988). Mendefinisikan gaya belajar sebagai kebiasaan belajar yang disenangi oleh pembelajar. Keefe, (1979). Memandang gaya belajar sebagai cara seseorang dalam menerima, berinteraksi, dan memandang lingkungannya. Dunn dan Griggs (1988) memandang gaya belajar sebagai karakter biologis bawaan.

Gaya belajar atau learning style adalah suatu karakteristik kognitif, afektif dan perilaku psikomotoris, sebagai indikator yang bertindak yang relatif stabil untuk pebelajar merasa saling berhubungan dan bereaksi terhadap lingkungan belajar (NASSP dalam Ardhana dan Willis, 1989 : 4). 
Definisi yang lebih menjurus pada gaya belajar bahasa dan yang dijadikan panduan pada penelitian ini dikemukakan oleh Oxford (2001:359) dimana gaya belajar didefinisikan sebagai pendekatan yang digunakan peserta didik dalam belajar bahasa baru atau mempelajari berbagai mata pelajaran.

Polya (1985), mengartikan pemecahan masalah sebagai suatu usaha mencari jalan keluar dari suatu kesulitan guna mencapai suatu tujuan yang tidak segera dapat dicapai.Sedangkan kegiatan pemecahan masalah itu sendiri merupakan kegiatan manusia dalam menerapkan konsep-konsep dan aturan-aturan yang diperoleh sebelumnya (Dahar,1989-1991).

Namun kejadian yang penulis temukan dilapangan adanya kejenuhan yang di alami siswa dalam belajar khususnya belajar matematika,hal itu disebabkan oleh metode dan gaya belajar yang digunakan monoton,oleh karena itu,perlu adanya perubahan baik dalam segi motode belajar maupun gaya belajar sehingga siswa merasa senang dalam belajar matematika.

Berdasarkan uraian diatas maka penulis mengajukan penelitian yang berjudul" Pengaruh Pembelajaran Luar Kelas (Outdoor Learning) dan Gaya Belajar terhadap Kemampuan Pemecahan Masalah pada Siswa kelas VII SMP Negeri 05 Seluma".

Tujuan penelitian ini adalah Untuk mengetahui pengaruh Pembelajaran luar kelas (Outdoor Learning) terhadap kemampuan pemecahan masalah siswa kelas SMP Negeri 05 Seluma.

\section{Metode}

Berdasarkan variabel yang akan di teliti dalam penelitian ini, maka Jenis penelitian ini adalah penelitian eksperimen semu atau kuasi eksperimen (quasi experiment). Kuasi eksperimen atau disebut juga eksperimen semu adalah eksperimen yang dalam mengontrol situasi penelitian tidak terlalu ketat atau menggunakan rencangan tertentu dan/atau menunjukkan subjek penelitian secara tidak acak atau mendapatkan salah satu dari berbagai tingkat faktor penelitian (Rajab, 2009 : 51) Peneliti mengunakan Ekperimen semu (quasi ekperiment) karena dalam menggunakan populasi dan sampel tidak dilakukan acak, peneliti menggunakan dua kelas yaitu kelas $\mathrm{VII}_{1}$ dan kelas $\mathrm{VII}_{2}$ dari 6 kelas untuk dijadikan sampel, kelas $\mathrm{VII}_{1}$ dijadikan kelas Ekperimen $\left(\mathrm{X}_{1}\right)$ dan Kelas $\mathrm{VII}_{2}\left(\mathrm{X}_{2}\right)$ sebagai kelas kontrol.

\section{Hasil dan Pembahasan}

Penelitian ini dilaksanakan di kelas VII SMP Negeri 05 Seluma dengan mengambil sampel kelas 2 kelas yaitu kelas VII 1 sebagai kelas Ekperimen. Sedangkan untuk kelas kontrol yaitu kelas $\mathrm{VII}_{2}$. Bentuk perlakukan yang dilakukan yaitu pembelajaran luas kelas (Outdoor Learning) dan pembelajaran Konvensional. Proses pelaksanaan pembelajaran dilaksanakan berdasarkan RPP yang telah dirancang sebelumnya oleh peneliti, dengan pendekatan Pembelajaran luar kelas (Outdoor Learning) untuk kelas ekperimen dan pembelajaran konvensional untuk kelas kontrol.

Penelitian ini diawali dengan memberikan tes awal (pretest) kepada kedua kelas penelitian yang bertujuan untuk mengetahui kemampuan awal yang dimiliki oleh siswa. Kemampuan awal yang diukur yaitu kemampuan pemahaman konsep dan kemampuan pemecahan masalah. Selanjutnya setiap kelas diberikan pembelajaran dimana kelas ekperimen dengan pembelajaran diluar kelas (Outdoor Learning) dan pembelajaran konvensional untuk kelas kontrol. Pada kedua kelas tersebut diberikan tes akhir (postest) untuk mengetahui kemampuan pemahaman konsep dan kemampuan pemecahan masalah setelah dibrikan pembelajaran. Data hasil tes awal (pretest), tes akhit (postest) digunakan untuk menguji 
hipotesis penelitian. Secara umum penelitian ini bertujuan untuk menguji pengaruh pembelajarn diluar kelas (outdoor learning) dan pembelajaran konvensional terhadap kemampuan pemahaman konsep dan kemampuan pemecahan masalah.

Diskripsi data tes awal (pretest) bertujuan untuk memberikan gambaran kemampuan awal siswa, yaitu kemampaun pemahaman konsep dan kemampuan pemecahan masalah. Soal tes awal (pretest), yang diberikan berupa soal uraian.Tes untuk mengukur kemampuan awal pemahaman konsep terdiri 7 soal dan kemampuan pemecahan masalah 5 soal .Hasil tes awal dideskripsikan berdasarkan nilai rata-rata, nilai minimum dan nilai maksimum masing-masing kelas penelitian. Adapun didskripsi hasil tes dengan menggunakan skala $0-100$ untuk pemahaman konsep dan kemampuan pemecahan masalah ditunjukan tabel berikut :

Tabel : 1 Nilai Tes Awal Kemampuan Pemecahan masalah

\begin{tabular}{|l|c|c|c|}
\hline \multirow{2}{*}{ Kelas penelitian } & \multicolumn{3}{|c|}{ Pemahaman konsep } \\
\cline { 2 - 4 } & Min & Max & Rata-rata \\
\hline Kelas Ekperimen & 41 & 64 & 52.00 \\
\hline Kelas Kontrol & 30 & 53 & 44,71 \\
\hline
\end{tabular}

Data Tabel 1 menunjukkan bahwa rata-rata nilai pemecahan masalah siswa pada kelas ekperimen 52,00 dan kelas kontrol 44,71. Data tersebut mengidentifikasikan bahwa kemampuan pemecahan masalah pada kelas ekperimen dan kelas kontrol berbeda. Selain itu, nilai nilai maksimum pada kelas ekperimen 64 dan kelas kontrol 53. Hal ini menunjukkan rentang nilai awal pada kelas ekperimen dan kelas kontrol hampir sama. Hal ini dapat dinyatakan bahwa kemampuan awal kedua kelas masih rendah dan masih dibawah kreteria ketuntasan maksimum yang di tetapkan sekolah yaitu 75 . Data juga mengidentifikasikan bahwa kedua kelas penelitian memiliki distribusi yang homogen.

Tabel : 2 Nilai Tes Awal Kemampuan Pemecahan Masalah

\begin{tabular}{|l|c|c|c|}
\hline \multirow{2}{*}{ Kelas penelitian } & \multicolumn{3}{|c|}{ Kemampuan Pemecahan Masalah } \\
\cline { 2 - 4 } & Min & Max & Rata-rata \\
\hline Kelas Ekperimen & 37 & 64 & 52,00 \\
\hline Kelas Kontrol & 30 & 53 & 44,71 \\
\hline & & & \\
\hline
\end{tabular}

Data pada Tabel 2 menunjukkan bahwa rata-rata nilai pemecahan masalah siswa pada kelas ekperimen 52,00 dan kelas kontrol 44,71. Data tersebut mengidentifikasikan bahwa kemampuan Pemecahan masalah pada kelas ekperimen dan kelas kontrol berbeda. Selain itu, nilai nilai maksimum pada kelas ekperimen 64 dan kelas kontrol 53. Hal ini menunjukkan rentang nilai awal pada kelas ekperimen dan kelas kontrol hampir sama. Hal ini dapat dinyatakan bahwa kemampuan awal kedua kelas masih rendah dan masih dibawah kreteria ketuntasan maksimum yang di tetapkan sekolah yaitu 75. Data juga mengidentifikasikan bahwa keempat kelas penelitian memiliki distribusi yang homogen.

Tabel : 3 Tes Akhir (Postest) Kemampuan Pemecahan Masalah

\begin{tabular}{|l|c|c|c|}
\hline \multirow{2}{*}{ Kelas penelitian } & \multicolumn{3}{|c|}{ Pemahaman konsep } \\
\cline { 2 - 4 } & Min & Max & Rata-rata \\
\hline Kelas Ekperimen & 64 & 85 & 78,79 \\
\hline Kelas Kontrol & 59 & 82 & 73,86 \\
\hline
\end{tabular}


Data pada Tabel 3 menunjukkan bahwa rata-rata nilai pemecahan masalah siswa pada kelas ekperimen 78,79 dan kelas kontrol 73,86. Data tersebut mengidentifikasikan bahwa kemampuan pemecahan masalah pada kelas ekperimen dan kelas kontrol berbeda. Selain itu, nilai nilai maksimum pada kelas ekperimen 85 dan kelas kontrol 82 dan nilai terendah 64 dan kelas kontrol 82.Hal ini menunjukkan nilai lebih dari KKM yaitu 75 sehingga secara umum kemampuan pemecahan masalah siswa dengan diberikan pembelajaran luar kelas (Outdoor learning) di atas KKM dan lebih tinggi dari pada siswa yang diberikan pembelajaran konvensional. Data pemecahan masalah akhir siswa menunjukkan bahwa secara rata-rata kelas ekperimen lebih tinggi dari kelas kontrol. Data pada tabel 4.1 di atas menunjukkan bahwa rata-rata nilai pemecahan masalah siswa pada kelas ekperimen 85,71 dan kelas kontrol 80,84. Data tersebut mengidentifikasikan bahwa kemampuan pemecahan masalah pada kelas ekperimen dan kelas kontrol berbeda. Selain itu, nilai nilai maksimum pada kelas ekperimen 94 dan kelas kontrol 93 dan nilai terendah 71 dan kelas kontrol 66.Hal ini menunjukkan nilai lebih dari KKM yaitu 75 sehingga secara umum kemampuan pemecahan masalah siswa dengan diberikan pembelajaran luar kelas (Outdoor learning) di atas KKM dan lebih tinggi dari pada siswa yang diberikan pembelajaran konvensional.Data pemecahan masalah akhir siswa menunjukkan bahwa secara rata-rata kelas ekperimen lebih tinggi dari kelas kontrol.

Pengujian normalitas dan kemampuan kemampuan pemecahan masalah menggunakan Kolmogorov-Smirnov.Pembelajaran luar kelas (Outdoor Learning) Karena tarap siknifikan untuk pemecahan masalah pretest 0,672 , postest 0,053 lebih besar $0,05(5 \%)$ maka kedua data tersebut berdistribusi normal seperti pada tabel berikut :

Tabel : 4 Uji Normalitas Kemampuan pemecahan masalah Kelas Ekperiment

\begin{tabular}{|c|c|c|c|}
\hline \multicolumn{4}{|c|}{ One-Sample Kolmogorov-Smirnov Test } \\
\hline & & Pretest & Posttest \\
\hline & 28 & 28 \\
\hline \multicolumn{2}{|l|}{$\begin{array}{l}\text { N } \\
\text { Normal }\end{array}$} & 52,0000 & 85,7143 \\
\hline Parameters ${ }^{\mathrm{a}, \mathrm{b}}$ & Std. Deviation & 6,74949 & 6,28848 \\
\hline Most Extreme & Absolute & ,136 & , 164 \\
\hline \multirow[t]{2}{*}{ Differences } & Positive &, 116 & ,094 \\
\hline & Negative &,- 136 &,- 164 \\
\hline \multicolumn{2}{|c|}{ Test Statistic } &, 136 & 164 \\
\hline \multicolumn{2}{|c|}{ Asymp. Sig. (2-tailed) } & $199^{\mathrm{c}}$ &, $053^{\mathrm{c}}$ \\
\hline \multicolumn{4}{|c|}{$\begin{array}{l}\text { a. Test distribution is Normal. } \\
\text { b. Calculated from data. } \\
\text { c. Lilliefors Significance Correction. }\end{array}$} \\
\hline
\end{tabular}

Uji normalitas digunakan untuk mengetahui apaka sampel dalam penelitian ini berasal dari populasi berdistribusi normal. Uji normalitas dalam penelitian ini menggunakan uji normalitas Kosmogrov (KS). Hasil analisis uji normalitas dalam taraf signifikan 5\% pada masing-masing sampel sebagai berikut :

1. Analisis pre-test kemampuan pemecahan masalah siswa pada kelompok eksperimen diperoleh nilai $\mathrm{p}(\mathrm{sign})=0,199$. Karena nilai $\mathrm{p}>0,05$ maka $\mathrm{H}_{\mathrm{o}}$ diterima, sehingga dapat disimpulkan bahwa data yang diambil dari populasi yang berdistribusi normal. 
2. Analisis pos-test kemampuan pemecahan masalah siswa pada pada kelompok eksperimen di peroleh $=0,053$ maka $\mathrm{H}_{0}$ diterima,sehingga dapat disimpulkan bahwa data diambil dari populasi yang berdistribusi normal.

Pengujian normalitas dan kemampuan Pemecahan Masalah dan kemampuan pemecahan masalah menggunakan Kolmogorov-Smirnov.Pembelajaran luar kelas (Outdoor Learning) Karena tarap siknifikan untuk pemecahan masalah pretest 0,05, postest 0,144 lebih besar 0,05 $(5 \%)$ maka kedua data tersebut berdistribusi normal seperti pada tabel berikut :

Tabel 5 Uji Normalitas Kemampuan Pemahaman Konsep Kelas Kontrol One-Sample Kolmogorov-Smirnov Test

\begin{tabular}{|c|c|c|c|}
\hline & & Pretest & Posttest \\
\hline \multirow{3}{*}{$\begin{array}{l}\mathrm{N} \\
\text { Normal Parameters }\end{array}$} & & 28 & 28 \\
\hline & Mean & 52,0000 & 80,6429 \\
\hline & Std. Deviation & 6,74949 & 7,03544 \\
\hline \multirow{3}{*}{$\begin{array}{l}\text { Most Extreme } \\
\text { Differences }\end{array}$} & Absolute & , 136 & , 148 \\
\hline & Positive & , 116 & 112 \\
\hline & Negative &,- 136 &,- 148 \\
\hline Test Statistic & & , 136 & , 148 \\
\hline Asymp. Sig. (2-tailed) & & $199^{c}$ & $121^{\mathrm{c}}$ \\
\hline
\end{tabular}

Uji normalitas digunakan untuk mengetahui apaka sampel dalam penelitian ini berasal dari populasi berdistribusi normal. Uji normalitas dalam penelitian ini menggunakan uji normalitas Kosmogrov (KS). Hasil analisis uji normalitas dalam taraf signifikan 5\% pada masing-masing sampel sebagai berikut :

1. Analisis pre-test kemampuan pemecahan masalah siswa pada kelompok kelas kontrol diperoleh nilai $\mathrm{p}(\mathrm{sign})=0,199$. Karena nilai $\mathrm{p}>0,05$ maka $\mathrm{H}_{\mathrm{o}}$ diterima, sehingga dapat disimpulkan bahwa data yang diambil dari populasi yang berdistribusi normal.pos-test kemampuan pemecahan masalah siswa pada pada kelompok kelas kontrol di peroleh $=$ 0,121 maka $\mathrm{H}_{0}$ diterima, sehingga dapat disimpulkan bahwa data diambil dari populasi yang berdistribusi normal.

2. Analisis pre-test kemampuan pemecahan masalah siswa pada kelompok kontrol diperoleh nilai $\mathrm{p}(\mathrm{sign})=0,053$. Karena nilai $\mathrm{p}>0,05$ maka $\mathrm{H}_{\mathrm{o}}$ diterima, sehingga dapat disimpulkan bahwa data yang diambil dari populasi yang berdistribusi normal.

3. Analisis pos-test kemampuan pemecahan masalah siswa pada pada kelas kelompok kelas kontrol di peroleh $=0,076$ maka $\mathrm{H}_{0}$ diterima, sehingga dapat disimpulkan bahwa data diambil dari populasi yang berdistribusi normal.

Tabel 6 Uji Hipotesis Kemampuan pemahaman konsep

Tests of Between-Subjects Effects

\begin{tabular}{|c|c|c|c|c|c|c|}
\hline Source & $\begin{array}{c}\text { Type III Sum of } \\
\text { Squares }\end{array}$ & $\mathrm{df}$ & Mean Square & $\mathrm{F}$ & Sig. & $\begin{array}{l}\text { Partial Eta } \\
\text { Squared }\end{array}$ \\
\hline Corrected Model & $2621,337^{a}$ & 2 & 1310,668 & 1265,831 & ,000 & ,979 \\
\hline Intercept & 949,903 & 1 & 949,903 & 917,407 & ,000 & 945 \\
\hline Pretest & 2281,266 & 1 & 2281,266 & 2203,225 & 000 & ,977 \\
\hline Kelas & 340,071 & 1 & 340,071 & 328,438 & 000 & ,861 \\
\hline Error & 54,877 & 53 & 1,035 & & & \\
\hline Total & 328874,000 & 56 & & & & \\
\hline Corrected Total & 2676,214 & 55 & & & & \\
\hline
\end{tabular}

a. R Squared $=, 979$ (Adjusted R Squared $=, 979)$ 
Tabel 6 menunjukkan bahwa nilai R Squared =0,979 (Adjusted R Squared $=0,979$ ) siknifikan kecil dari 0,05 maka $\mathrm{H}_{1}$ diterima. Berarti terdapat pengaruh penerapan pembelajaran luar kelas (outdoor learning) terhadap kemampuan pemecahan masalah siswa kelas $\mathrm{VII}_{1}$ SMPN 05 Seluma.,besarnya pengaruh Pembelajaran luar kelas (outdoor learning) terhadap kemampuan pemecahan masalah adalah $97,9 \%$.

Tabel : 7 Uji Hipotesis Kemampuan pemecahan masalah Tests of Between-Subjects Effects

Dependent Variable: Postest

\begin{tabular}{|l|r|r|r|r|r|r|}
\hline Source & $\begin{array}{c}\text { Type III Sum of } \\
\text { Squares }\end{array}$ & df & Mean Square & \multicolumn{1}{|c|}{ F } & Sig. & $\begin{array}{c}\text { Partial Eta } \\
\text { Squared }\end{array}$ \\
\hline Corrected Model & $2689,842^{\mathrm{a}}$ & 2 & 1344,921 & 958,435 &, 000 &, 973 \\
Intercept & 949,869 & 1 & 949,869 & 676,908 &, 000 &, 927 \\
Pretest & 2329,771 & 1 & 2329,771 & 1660,271 &, 000 &, 969 \\
Kelas & 360,071 & 1 & 360,071 & 256,599 &, 000 &, 829 \\
Error & 74,372 & 53 & 1,403 & & & \\
Total & 390210,000 & 56 & & & & \\
Corrected Total & 2764,214 & 55 & & & & \\
\hline
\end{tabular}

a. R Squared $=, 973$ (Adjusted R Squared $=, 972$ )

Tabel 7, diperoleh bahwa nilai R Squared $=0,973$ (Adjusted R Squared $=0,972$ ) siknifikan kecil dari 0,05 maka $\mathrm{H}_{1}$ diterima. Berarti perdapat pengaruh penerapan pembelajaran luar kelas (outdoor learning) terhadap kemampuan pemecahan masalah siswa kelas VII ${ }_{1}$ SMPN 05 Seluma.. besarnya pengaruh Pembelajaran luar kelas (outdoor learning) terhadap kemampuan pemecahan masalah adalah 97,3\%.

Berdasarkan skor yang telah dianalisis, hasil kemampuan pemecahan masalah matematika siswa menunjukkan bahwa kelas eksperimen memiliki rata-rata lebih tinggi yakni 78,79 dibandingkan dengan kelas kontrol yaitu 73,86. Pembelajaran luar kelas (outdoor learning) membuat siswa lebih aktif dan rajin dalam belajar. Hal ini yang mempengaruhi hasil belajar siswa memiliki kemampuan pemecahan masalah yang lebih tinggi.

Faktor lain adalah konsep yang diberikan kepada siswa selalu berkaitan dengan permasalahan yang biasa ditemui siswa sehari-hari sehingga siswa lebih cepat menangkap maksud dari masalah yang diberikan. Sedangkan pada kelas kontrol pembelajaran yang dilakukan dengan konvensional terlihat siswa belajar seperti biasanya, mendegarkan cerama guru, mengerjakan latihan dan menjawab soal-soal, kegiatan belajar ini membuat siswa cepat bosan dan tidak bersemagat untuk memahami materi dengan baik. Siswa malas berfikir dan hanya menunggu intruksi dari guru.

Berdasarkan hasil uji analisis yang telah dilakukan dengan program spss menjadi nilai sig $(0,000)<0,05$ pada tabel test of between subjects effect, maka dihasilkan hipotesis $\mathrm{H}_{0}$ di tolak pada taraf signifikansi 0,05 artinya dengan menggunakan taraf perbedaan pemecahan masalah antara siswa yang mengikuti pembelajaran luar kelas (outdoor learning) dengan pembelajaran konvensional. Hal ini memberikan kesimpulan bahwa pembelajaran luar kelas (outdoor learning) memberikan pengaruh terhadap kemampuan pemecahan masalah matematika sisiwa. Hal ini mendukung hasil penelitian: there are significant differences in students' mathematical problem solving abilities between before and after being given ethnomathematics learning with outdoor learning models. Also, the mathematical problem solving abilities of students after being given ethnomathematics with outdoor learning models 
were higher than before being given the learning models (Widada et al., 2019). Media pembelajaran kontekstual dapat dengan efektif menghasilkan pola (pattern) yang dapat dengan mudah siswa menyusun peryataan awal (conjecture) dan dengan aktivitas matematisasi vertikal, siswa dengan bantuan teman yang lebih mampu atau guru dapat mencapai konsep dan prinsip yang sedang mereka pelajari (Widada, 2015). Juga, the influence of contextual learning model based on the cognitive conflict on the ability of students to understand the concept of mathematics SMP better than conventional learning model when controlled by cognitive conflict covariate. These two conclusions mean that the ability to comprehend the concept and problem solving of math students of Bengkulu City Junior which through contextual learning model of mathematics based on cognitive conflict of students experience a very high increase. Thus, it was suggested to the junior mathematics teacher to turn the conventional learning model with the contextual learning model based on students' cognitive conflict (Herawaty \& Widada, 2018).

Besar pengaruh dari nilai tersebut memberikan gambaran bahwa pembelajaran luar kelas (outdoor learning) sangat memberikan efek pada kemampuan pemecahan masalah matematika siswa. Selain itu permasalahan yang diberikan dalam pembelajaran luar kelas (outdoor learning) dapat digunakan siswa untuk mengeksplorasi kompetisi yang dimiliki serta dapat mengembangkan kemampuan berfikir siswa dalam memahami masalah-masalah matematika.

\section{Simpulan}

Berdasarkan hasil analisis data, maka terdapat pengaruh pembelajaran luar kelas (Outdoor Learning) terhadap Kemampuan pemecahan masalah kelas (outdoor learning dapat digunakan dalam untuk meningkatkan kemampuan pemecahan masalah matematika.

\section{DAFTAR PUSTAKA}

Adelia V, Metode Mengajar Anak di Luar Kelas (Outdoor learning). Jogjakarta: DIVA Press. 2012. Adelia ,Vera. 2012. Metode Mengajar Anak di Luar Kelas (Ourdoor Study). Divapress: Yogyakarta Ahmadi,A dan Prasetya.J Strategi Belajar Mengajar untuk Fakultas Tarbiyah Komponen MKDK. Bandung: Pustaka Setia. 2005

Amin, C. (2008). Memupuk. Tradisi Ilmiah Siswa Sekolah Dasar Menggunakan Metode Outdoor Learning Process (OLP). Makalah Seleksi Simposium Tahunan Penelitian Pendidikan. 2008.

Herawaty, D., \& Widada, W. (2018). The Influence of Contextual Learning Models and the Cognitive Conflict to Understand Mathematical Concepts and Problems Solving Abilities. Advances in Social Science, Education and Humanities Research, 218(ICoMSE 2017), 96-102. https://doi.org/10.2991/icomse-17.2018.17

Widada, W. (2015). Proses Pencapaian Konsep Matematika dengan Memanfaatkan Media Pembelajaran Kontekstual. Jurnal Penelitian Pendidikan Matematika Dan Sains, 22(1), 31-44. Retrieved from https://id.wikipedia.org/wiki/Pembelajaran

Widada, W., Herawaty, D., Falaq, A., Anggoro, D., Yudha, A., \& Hayati, M. K. (2019). Ethnomathematics and Outdoor Learning to Improve Problem Solving Ability. Advances in Social Science, Education and Humanities Research, Volume 295, 295(ICETeP 2018), 13-16. 